\title{
AS SOCIEDADES DE PROPÓSITO ESPECÍFICO NA CONDUÇÃO DAS OPERAÇÕES DE SECURITIZAÇÃ̃O DE CRÉDITOS IMOBILIÁRIOS
}

\section{SPECIAL PURPOSE ENTITY AS MEANS TO MATERIALIZE SECURITIZATION OPERATIONS OF REAL ESTATE CREDITS}

${ }^{1}$ Carolina Catizane de Oliveira Almeida

\begin{abstract}
RESUMO
O presente artigo tem por escopo demonstrar as vantagens da utilização das sociedades de propósito específico nas operações de securitização, por meio de estudo atento, análise do tipo societário e do instituto em comento. Assim, este trabalho versa, basicamente, sobre o conceito, natureza, os meios de constituição, os direitos e deveres dos sócios e a extinção da modalidade societária denominada sociedade de propósito específico, considerada a partir do estudo aprofundando da legislação, doutrina e jurisprudência que tratam a respeito. $\mathrm{O}$ presente artigo trata ainda das operações de securitização, trazendo um breve histórico de seu desenvolvimento no Brasil, bem como a sua conceituação, além de apresentar a normatização a ele concernente, expondo por fim, a utilidade em se empregar o tipo societário em tela nas operações de securitização de créditos imobiliários.
\end{abstract}

Palavras-chave: Sociedade de propósito específico spe, Securitização, Créditos imobiliários

\begin{abstract}
This article aims to demonstrate the advantages of using special purpose entities in securitization transactions, through careful study, analysis of this corporate type and the institute under discussion. Thus, this work argues basically on the concept, nature, means of constitution, the rights and duties of partners and the extinction of the corporate type named special purpose entity, what is done after a detailed study of related legislation, doctrine and jurisprudence. This article also covers securitization transactions, bringing a brief history of its development in Brazil, as well as its concept, related laws, and finally exposes the benefit of employing the special purpose entity to materialize securitization operations of real estate credits.
\end{abstract}

Keywords: Special purpose entity, Securitization, Real estate credits

\footnotetext{
${ }^{1}$ Mestra em Direito Empresarial pela Faculdade de Direito Milton Campos, FDMC, Minas Gerais, MG, (Brasil). $1^{\text {a }}$ Escrevente de Registro de Imóveis e Anexos de Taquaritinga/SP, RITDPJ, São Paulo, SP. (Brasil). E-mail.: carolina.catizane@gmail.com
} 


\section{INTRODUÇÃO}

Há muito, os títulos de crédito vêm sendo empregados em finalidades que ultrapassam os objetivos de mobilização e movimentação de recursos e, visam também a sua angariação nos mercados de capital e financeiro.

Deste modo, tendo em vista o desenvolvimento imobiliário ocorrido no país, nos últimos anos, fomentado pelo crédito ofertado à população para aquisição de imóveis, em especial por meio da atuação dos bancos públicos, com condições mais atrativas para a realização dos financiamentos, foram instituídas novas modalidades de investimentos em bens imóveis, visando a atração de mais capital tanto nacional quanto estrangeiro.

Assim, foi criado o instituto jurídico da securitização de créditos, que se trata da criação de títulos mobiliários ligados a um ativo, possibilitando a minimização dos riscos, facilitando a atração de investimentos a um custo inferior.

Neste contexto, a securitização é relevante ferramenta para a atração de recursos, especialmente para as instituições financeiras.

Portanto, trata-se a securitização da emissão de títulos, que possuem como meio de liquidação a entrada de capital provocada por este mesmo crédito.

Deste modo, o presente artigo tem por pretensão, apresentar a conceituação do que são as operações de securitização, demonstrando ainda, que de maneira breve, o histórico de sua evolução desde o seu surgimento nos Estados Unidos na década de 1970 até os dias de hoje, tendo como enfoque principal o cenário brasileiro.

A sociedade de propósito específico - SPE, por sua vez, é inteiramente atrelada às operações de securitização de créditos imobiliários, já que estas últimas tratam de operações financeiras em que uma SPE emite títulos em benefício dos investidores, direta ou indiretamente, aplicando o importe alcançado para adquirir os direitos de pagamento, que comporão a principal fonte de pagamento de tais títulos.

Portanto, além de tratar acerca das operações de securitização e seu desenvolvimento, tem-se também a pretensão de delinear a utilização da SPE em tais operações, bem como apresentar os benefícios trazidos por sua utilização.

Tendo em vista que a securitização pode ser empregada tanto pelo setor privado quanto pelo setor público e que, consiste em um importante meio tanto para o 
financiamento de projetos quanto para a edificação de habitações, justifica-se a realização de pesquisa a seu respeito e a elaboração do presente artigo.

\section{2- $\quad$ AS OPERAÇÕES DE SECURITIZAÇÃO DE CRÉDITOS}

O termo securitização tem origem na palavra inglesa security, que tem por significado valor imobiliário. Assim, tem-se que o uso da securitização refere-se à criação e emprego de valores mobiliários.

Para Natália Cristina Chaves $^{1}$, as primeiras securitizações ocorreram nos Estados Unidos da América, em fevereiro de 1970, ocasião em que a Advance Corporation Mortgage emitiu valores mobiliários garantidos por créditos hipotecários, tendo por seguradora da operação a Ginnie Mae.

A securitização surgiu nos Estados Unidos, na década de 1970, na tentativa do governo de fomentar o mercado secundário para títulos lastreados em hipotecas, em virtude da grande demanda por recursos para financiar a habitação ante a pequena oferta da capital ${ }^{2}$.

Quando de seu surgimento ainda na década de 1970, a securitização para o mercado financeiro consistia na estruturação e venda de investimentos negociáveis, de modo a passar o risco integral que em regra seria de um único credor a distintos investidores. Isto é dizer que à época a securitização era empregada com a finalidade de angariar recursos como opção para emprego de débitos bancários.

Embora tenham surgido há poucas décadas, as operações de securitização já são muito utilizadas em quase todo o mundo. Desde sua origem, o desenvolvimento de tais operações marchou em unidade com o progresso do mercado de capitais em todos os países em que são utilizadas e, em específico nos Estados Unidos.

A securitização é um importante instrumento para separar o risco de recebíveis daqueles da sociedade que o originou. Tal operação tem por objetivo viabilizar que uma sociedade originadora possa conseguir recursos sem que para tal necessite comprometer

\footnotetext{
${ }^{1}$ CHAVES, Natália Cristina. Direito empresarial: securitização de crédito. 1. ed. Belo Horizonte: Del Rey, 2006. p. 24.

${ }^{2}$ COELHO, Lívia Alves Viesnevski Fróes. Securitização. São Paulo: Potifícia Universidade Católica de São Paulo, 2007.
} 
o seu limite de crédito perante credores e ainda, sem que com isso tenha quaisquer prejuízos relacionados ao seu balanço.

$\mathrm{Na}$ prática, a estrutura desta operação possui três figuras principais. O originador, o emissor e o investidor.

$\mathrm{O}$ originador é a figura que possui um ativo a ser securitizado, ele transfere esse ativo ao emissor, que é a um veículo criado para este fim, que pode ser uma sociedade, um fundo ou um trust. O emissor, por sua vez, emitirá títulos lastreados nos créditos recebidos, captando assim recursos de investidores que serão repassados ao originador, como pagamento pela cessão dos créditos ou de outro ativo utilizado na operação. Caminha $^{3}$ define as operações de securitização nos seguintes termos:

\begin{abstract}
Do ponto de vista financeiro, a securitização em sentido estrito é uma operação por meio da qual se mobilizam ativos - presentes ou futuros - que, de outra maneira, não teriam a possibilidade de se autofinanciar ou gerar renda presente. A possibilidade de se emitirem títulos ou valores mobiliários a partir de uma operação de cessão ordinária é uma forma de se mobilizarem créditos gerados nas mais diversas operações, ainda que tais créditos só venham a ser realizados no futuro.

Com a securitização, o agente econômico que origina créditos pode diluir os riscos de sua carteira de recebíveis, mesmo que ela seja futura, e adiantar receitas a ela referentes ou financiar projetos, pela emissão de títulos lastrados nessa carteira. Assim, a função econômica da securitização pode ser resumida em três aspectos: mobilizar riquezas, dispersar riscos e desintermediar o processo de financiamento.

Sob a ótica jurídica, a securitização pode ser definida como a estrutura composta por um conjunto de negócios jurídicos - ou um negócio jurídico indireto, como se verá adiante - que envolve a cessão e a segregação de ativos em uma sociedade, ou um fundo de investimento, que emite títulos garantidos pelos ativos segregados. Esses títulos são vendidos a investidores e os recursos coletados servem de contraprestação pela cessão de ativos.
\end{abstract}

Desta maneira, a securitização é a operação em que o originador repassa seus créditos ao emissor e este, tendo adquirido os créditos do originador, lastreado nestes realiza a emissão dos títulos e valores mobiliários e os oferta no mercado de capitais.

Com a oferta pública dos títulos e valores mobiliários, o emissor tem a possibilidade de realizar o pagamento do originador pelos créditos que lhes cedeu.

Portanto, nas operações de securitização, determinados ativos são separados do patrimônio do originador, com a posterior emissão de títulos que representem o conjunto de ativos. Deste modo, os ativos apartados do conjunto de bens do originador representam o lastro para as operações de securitização.

${ }^{3}$ CAMINHA, Uinie. Securitização. $2^{\mathrm{a}}$ edição. São Paulo: Saraiva, 2007. pp. 38-39. 
É, portanto vantajosa a utilização da securitização pelas sociedades originadores por lhes permitir receber antecipadamente créditos aos quais apenas faria jus no futuro. Ademais, a securitização permite ainda o repasse dos riscos do originador a terceiros, de maneira que estes quedam protegidos tanto dos riscos de crédito, quanto dos riscos de falência do primeiro.

Sobre esta operação Caminha ${ }^{4}$ destaca:

Em linhas gerais, nessa operação, o originador segrega de seu patrimônio geral determinado ativo em um veículo de propósito exclusivo, por meio de uma cessão de crédito ou de contrato. A partir do lastro representado pelo ativo cedido, o veículo de propósito exclusivo emitirá títulos a serem adquiridos por investidores, que, assim, antecipam uma receita que só no futuro seria realizada pelo originador.

$\mathrm{O}$ ativo pode ser um fluxo de recebimentos, um bem, ou um direito de qualquer ordem, desde que possa ser cedido e gerar uma renda. Podem ainda se lastro de operações de securitização as receitas futuras, desde que determináveis. O título a ele associado deve ser estruturado de acordo com os objetivos de cada operação, sendo o instrumento utilizado para transferir o resultado financeiro originado pelo ativo aos investidores.

A securitização surgiu como uma forma de captação de recursos sem a intermediação financeira e seus custos inerentes.

O empresário, denominado originador, na operação, consegue se financiar pela captação da poupança popular, oferecendo juros razoáveis, melhores do que aqueles pagos pelo mercado financeiro.

Neste sentido, Melhim Namen Chalhub ${ }^{5}$ :

\begin{abstract}
A securitização, atende, fundamentalmente, do ponto de vista do tomador de recursos, ao objetivo de obtenção de uma fonte alternativa de recursos, com redução de custos, seja por via direta, mediante a diminuição da taxa de juros, ou por via indireta, com o encurtamento dos prazos de retorno de ativos imobilizados, por títulos de dívidas e, do ponto de vista do investidor, pode viabilizar o objetivo de dispor de uma modalidade de investimento que pode oferecer vantagens, comparativamente com outros papéis do mercado, em razão da maior rentabilidade e maior segurança, pois a redução de riscos ou sua relativa diminuição, é um dos propósitos fundamentais do processo de securitização.
\end{abstract}

Dessa forma, a securitização traz vantagens para o empresário, que necessita de buscar capital, e para o investidor, que pretende remunerar melhor seu patrimônio.

A securitização no mercado de hipoteca foi tão sem sucedida como fonte de captação de recursos que esta operação também passou a ser realizada em recebíveis de cartões de crédito, financiamento de automóveis, contratos de leasing e outros.

\footnotetext{
${ }^{4}$ CAMINHA, Uinie. Aspectos conceituais da securitização. Estudos Avançados de Direito EmpresarialContratos, direito Societário e Bancário, Rio de Janeiro: Editora Campus, 2012. ${ }^{5}$ CHALHUB, Melhim Namem. Negócio Fiduciário. Rio de Janeiro: Editora Renovar, 2000.
} 
No Brasil, de igual forma, a securitização, não se limita ao mercado Imobiliário, ao contrário, está presente em diversos segmentos. Entretanto, para atingir ao tema proposto, o artigo limitar-se-á à análise deste setor.

\section{1- AS OPERAÇÕES DE SECURITIZAÇÃO DE CRÉDITOS NO BRASIL}

No Brasil, apenas a partir dos anos 90 foram concretizadas as primeiras operações de securitização e tal se deu no cenário internacional. A primeira operação com tais características por sociedade brasileira foi realizada pela Embratel e a segunda pela companhia Varig.

Uma das operações pioneiras de securitização ocorreu no ano de 1994, época em que a matéria ainda não era ainda objetos de normatização. Tal se deu quando da emissão de debêntures pela sociedade empresária Mesbla Trust, com lastro em créditos gerados pela Mesbla S.A.

Além de ter sido uma das primeiras operações desta modalidade no país, a operação em comento destacou-se ainda em virtude da falência da Mesbla S.A. após a emissão destes títulos. À época, a falência da sociedade originadora dos créditos embora tenha causado surpresa e estranheza no mercado, obteve resultado final positivo, eis que os investidores perceberam o retorno financeiro dos investimentos exatamente conforme programação inicial, já os ativos da Mesbla Trust, entidade emissora, foram separados daqueles da Mesbla S.A., originadora falida.

Após tal operação, o cenário brasileiro de securitização pouco se movimentou até a normatização para duas novas modalidades de Entidades Emissoras, as denominadas companhias securitizadoras e os fundos de recebíveis.

Até então, as operações realizadas utilizavam-se da estrutura da cessão de direitos creditórios pela empresa originadora a uma sociedade de propósito específico, que em geral era constituída sob a modalidade de sociedade anônima ou sociedade limitada, à qual cabia a emissão de títulos que eram lastreados em tais direitos creditórios.

Assim, até o advento de legislação específica para as companhias securitizadoras e os fundos de recebíveis, tais operações eram em regra realizada por meio das sociedades de propósito específico. 


\title{
2.2- AS OPERAÇÕES DE SECURITIZAÇÃO DE CRÉDITOS IMOBILIÁRIOS NO BRASIL
}

O mercado brasileiro de securitização de carteiras pulverizadas de créditos imobiliários iniciou-se apenas a partir da edição da lei $n^{\circ} 9.514 / 1997^{6}$, que trouxe o sistema financeiro imobiliário - SFI, com vistas a aperfeiçoar o Sistema Financeiro da Habitação (SFH), normatizado pela Lei no 4.830/1964 .

Embora a Lei $\mathrm{n}^{\circ} 9.514 / 1997^{8}$ apenas tratasse das questões mais importantes relacionadas às operações de securitização de recebíveis imobiliários, tal legislação expressou o empenho das autoridades brasileiras em normatizá-la no país de maneira a oferecer aos investidores segurança em relação à sua licitude.

Em relação ao conceito de securitização de recebíveis imobiliários, em seu artigo $8^{\circ}$ a Lei $n^{\circ} 9.514 / 1997^{9}$ fixou o seguinte:

\begin{abstract}
Art. $8^{\circ}$ A securitização de créditos imobiliários é a operação pela qual tais créditos são expressamente vinculados à emissão de uma série de títulos de crédito, mediante Termo de Securitização de Créditos, lavrado por uma companhia securitizadora, do qual constarão os seguintes elementos:

I - a identificação do devedor e o valor nominal de cada crédito que lastreie a emissão, com a individuação do imóvel a que esteja vinculado e a indicação do Cartório de Registro de Imóveis em que esteja registrado e respectiva matrícula, bem como a indicação do ato pelo qual o crédito foi cedido;

II - a identificação dos títulos emitidos;

III - a constituição de outras garantias de resgate dos títulos da série emitida, se for o caso.

Parágrafo único. Será permitida a securitização de créditos oriundos da alienação de unidades em edificação sob regime de incorporação nos moldes da Lei $\mathrm{n}^{\circ}$ 4.591, de 16 de dezembro de 1964.
\end{abstract}

Após o advento da Lei ${ }^{\circ}$ 9.514/1997 ${ }^{10}$ seguiram-se as Resoluções nos 2.493/98 e 2.573/98, ambas expedidas pelo Banco Central do Brasil ("Banco Central") e revogadas pela Resolução no 2.686, de 27 de janeiro de 2000. A Resolução no 2.686/00, ainda em vigor, estabelece as condições gerais para a securitização de recebíveis financeiros originados por instituições financeiras.

\footnotetext{
${ }^{6}$ Brasil. Lei no. 9.514, de 20 de novembro de 1997. Diário Oficial da União, 21 nov. 1997, retificado em 24 nov. 1997.

${ }^{7}$ Brasil. Lei no ${ }^{\circ}$ 4.380, de 21 de agosto de 1964. Diário Oficial da União, 11 set. 1964.

${ }^{8}$ Brasil. Lei no ${ }^{\circ}$ 9.514, de 20 de novembro de 1997. Diário Oficial da União, 21 nov. 1997, retificado em 24 nov. 1997.

${ }_{9}^{9}$ Brasil. Lei no .9 .514 , de 20 de novembro de 1997. Diário Oficial da União, 21 nov. 1997, retificado em 24 nov. 1997.

${ }^{10}$ Brasil. Lei no. 9.514, de 20 de novembro de 1997. Diário Oficial da União, 21 nov. 1997, retificado em 24 nov. 1997.
} 
Sobre a análise do desempenho do mercado de securitização de créditos imobiliários no país no ano de 2004, as palavras de Chuck Spragins, constantes de seu artigo intitulado "A infraestrutura da securitização imobiliária" publicado em 25 de maio de 2005 na Gazeta Mercantil, veja-se:

Em 2003 o mercado alcançou um volume de apenas R \$ 36,3 milhões.

A partir dessa base, representando apenas $2 \%$ das emissões de securitização daquele ano, o mercado de securitização imobiliário cresceu $1.558 \%$, alcançando um volume de $\mathrm{R} \$ 602,4$ milhões, equivalente a $16,2 \%$ do mercado em 2004. No primeiro trimestre deste ano o volume correspondeu a $6,9 \%$ do mercado no período

(...)

Embora o crescimento de 2003 para 2004 tenha sido considerável e o volume de emissões realizadas importante, a tecnologia de securitização imobiliária está longe do seu potencial de contribuição macroeconômica.

Nos mercados onde a securitização está mais consolidada, operações com lastro em carteiras pulverizadas de créditos imobiliários figuram entre as mais representativas.

A título de exemplo, nos EUA o volume de emissões de operações deste tipo corresponde a mais de $60 \%$ do produto interno bruto daquele país.

No Brasil, onde o mercado está apenas começando, operações do mesmo tipo não representam nem $1 \%$ do PIB.

Para continuar o ritmo de crescimento alcançado no ano passado, a infraestrutura do mercado de securitização imobiliário tem que ser aperfeiçoada.

Sobre o cenário do mercado imobiliário no país por ocasião da criação do sistema financeiro imobiliário - SFI, as ponderações de Débora Catizane de Oliveira ${ }^{\mathbf{1 1}}$, in verbis:

Em termos gerais, o SFI criou o procedimento de securitização de créditos imobiliários e instituiu o regime fiduciário sobre tais créditos, de molde a estabelecer garantias nas operações de financiamento, com o escopo de privilegiar, de forma precípua, o desenvolvimento do mercado dos chamados bens de raiz, facilitando, assim, a aquisição da casa própria pelos brasileiros. Essa nova modalidade de financiamento difere-se daquela comum, adotada pelo $\mathrm{SFH}$, em virtude, basicamente, de duas inovações, a saber, possibilidade de se constituir alienação fiduciária quanto aos créditos decorrentes do financiamento, e de se transferir ou ceder esses créditos às companhias de capitalização.

O certificado de recebíveis imobiliários está fixado no artigo $6^{\circ}$ da Lei $n^{\circ}$ 9.514/1997 ${ }^{12}$, que estabelece que o CRI é o título de crédito nominativo, de livre negociação, lastreado em créditos imobiliários e constitui promessa de pagamento em dinheiro, podendo ser emitido exclusivamente por companhias securitizadoras.

11 OLIVEIRA, Débora Catizane de. Certificados de Recebíveis Imobiliários e seus Reflexos no Desenvolvimento do Mercado Imobiliário. Nova Lima: Faculdade de Direito Milton Campos/ FDMC, 2014

${ }^{12}$ Brasil. Lei no ${ }^{\circ}$ 9.514, de 20 de novembro de 1997. Diário Oficial da União, 21 nov. 1997, retificado em24 nov. 1997. 
$\mathrm{O}$ artigo $7^{\circ}$ da mesma lei ${ }^{13}$ dispõe acerca das características do CRI, que são as seguintes:I - nome da companhia emitente;

II - número de ordem, local e data de emissão;

III - denominação "Certificado de Recebíveis Imobiliários";

IV - forma escritural;

$\mathrm{V}$ - nome do titular;

VI - valor nominal;

VII - data de pagamento ou, se emitido para pagamento parcelado, discriminação dos valores e das datas de pagamento das diversas parcelas; VIII - taxa de juros, fixa ou flutuante, e datas de sua exigibilidade, admitida a capitalização;

IX - cláusula de reajuste, observada a legislação pertinente;

$\mathrm{X}$ - lugar de pagamento;

XI - identificação do Termo de Securitização de Créditos que lhe tenha dado origem.

$\S 1^{\circ} \mathrm{O}$ registro e a negociação do CRI far-se-ão por meio de sistemas centralizados de custódia e liquidação financeira de títulos privados.

$\S 2^{\circ}$ O CRI poderá ter, conforme dispuser o Termo de Securitização de Créditos, garantia flutuante, que lhe assegurará privilégio geral sobre o ativo da companhia securitizadora, mas não impedirá a negociação dos bens que compõem esse ativo.

Acerca do CRI, os esclarecimentos tecidos por Jean Carlos Fernandes ${ }^{14}$ :

Não obstante assuma a forma escritural, o CRI é vinculado ao Termo de Securitização de Crédito (papelizado), lavrado por uma companhia securitizadora, do qual constarão:

I- a identificação do devedor e o valor nominal de cada crédito que lastreie a emissão, com a individuação do imóvel a que esteja vinculado e a indicação do Cartório de Registro de Imóveis em que esteja registrado e respectiva matrícula, bem como a indicação do ato pelo qual o crédito foi cedido; II- a identificação dos títulos emitidos; e III- a constituição de outras garantias de resgate dos títulos da série emitida, se for o caso.

Uma vez que o CRI tem como qualidades de destaque o seu elevado índice de rendimento, isenção do imposto de renda, além do fomento à captação de recursos, entende-se que é um meio que permite a mobilidade do crédito com segurança e agilidade, cuja utilização além de importante para o desenvolvimento do setor imobiliário, está em constante ascensão.

Apesar do advento do sistema financeiro imobiliário e do constante incremento em sua utilização, se comparado ao uso de tais operações no exterior, o mercado nacional de securitização desenvolve-se de maneira mais acanhada, entretanto a utilização do CRI vem desenvolvendo-se constantemente e em breve deverá ser

\footnotetext{
${ }^{13}$ Brasil. Lei no ${ }^{\text {. 9.514, de }} 20$ de novembro de 1997. Diário Oficial da União, 21 nov. 1997, retificado em 24 nov. 1997.

14 FERNANDES, Jean Carlos. Teoria contemporânea dos títulos de crédito: imperativos principiológicos sob a ótica das teorias pós-positivistas. 1. ed. Belo Horizonte: Arraes Editores, 2012. p.53.
} 
considera uma das alternativas mais atraentes para a realização tanto de financiamentos quanto de investimentos no setor imobiliário. Tal se dá em virtude da existência de maior flexibilidade e força da legislação concernente a tal título.

Apesar do advento do sistema financeiro imobiliário e do constante incremento em sua utilização, se comparado ao uso de tais operações no exterior, o mercado nacional de securitização desenvolve-se de maneira mais acanhada.

\section{3- $\quad$ As sociedades de propósito específico - SPE e sua utilização na condução das operações de securitização de créditos imobiliários}

A sociedade de propósito específico, também chamada sociedade de objeto único, trata-se de uma sociedade empresária, que tem, como principal característica, ter sua existência diretamente ligada ao alcance de um objetivo específico, previamente determinado. Ou seja, tal sociedade é constituída exclusivamente para o desempenho de um único projeto.

Assim, pode-se dizer que é uma sociedade empresária que possui um objeto específico, ou seja, o instrumento para o desempenho de um projeto, que dura apenas enquanto perdurar o projeto que lhe deu causa. Dessa maneira, não pode ter o seu objeto social alterado, nem expandido.

Embora expressamente normatizada pelo CC/2002 como sociedade empresária, ao ser constituída, a sociedade de propósito específico deverá adotar uma das modalidades societárias legais. Uma vez adotado um tipo societário, este concederá à SPE suas principais características.

Deste modo, a SPE será constituída conforme a sociedade empresária que adote, com a elaboração de contrato ou estatuto social, registro perante a Junta Comercial e inscrição no Cadastro Nacional das Pessoas Jurídicas, funcionando como qualquer outra sociedade empresária até o alcance da finalidade pretendida, que em regra ocasionará o encerramento de suas atividades, após o cumprimento de todos os seus deveres.Ainda que possua prazo de duração determinado, consiste a SPE em uma sociedade autônoma que, ao reunir o interesse de duas ou mais pessoas, bem como os seus recursos, possui um objeto específico e previamente determinado. Embora o 
objetivo da SPE deva ser determinado, pode esse consistir no desempenho de diferentes atividades, desde que específicas, eis que a modalidade em estudo tem por fim o desempenho de um projeto exclusivo.

A sociedade de propósito específico surgiu no Brasil com escopo similar ao da joint venture dos Estados Unidos, ou seja, por meio da conexão entre diferentes indivíduos, dar cumprimento a determinada atividade social, por prazo determinado, prazo este na maior parte das vezes adstrito ao alcance do objetivo visado.

Desse modo, no cenário brasileiro, os contratos de joint venture implicam a criação de uma sociedade organizada em conformidade com uma das modalidades existentes em nosso ordenamento jurídico, por sociedades que visem desempenhar atividades comuns.

A SPE, por sua vez, surgiu num cenário em que se fazia necessário o surgimento de novos tipos societários para a consecução de um projeto ou mais projetos determinados, entre dois ou mais participantes.

Dessa maneira, num contexto em que se fazia necessária a criação de uma modalidade empresária que possibilitasse o desenvolvimento de projetos específicos, entre duas ou mais pessoas, surge a Sociedade de Propósito Específico - SPE inspirada na Special Purpose Entity, do Direito norte americano, também conhecida como Special Purpose Company, Special Purpose Vehicle ou Shell Company, que serviu de inspiração para a normatização nacional.

Conforme dito, uma vez que visa a um fim específico, alcançado o seu objeto ou a ação pretendida, a SPE é extinta.

Segundo Borba:

(...) a SPE não tem interesse próprio, não cumpre um objeto social próprio, não se destina a desenvolver uma vida social. Trata-se do que se poder chamar uma sociedade ancilar, mero instrumento de sua controladora. A rigor, essas sociedades nascem para prestar um serviço a sua controladora, para cumprir uma simples etapa de um projeto, ou até mesmo para desenvolver um projeto da controladora. Normalmente, cumprido esse projeto, o seu destino é a liquidação. Nascem, normalmente, já marcadas para morrer. ${ }^{15}$

${ }^{15}$ BORBA, José Edwaldo Tavares. Direito Societário. 9a ed. Rio de Janeiro: Renovar, 2004, p. 518. 
Desde o seu surgimento, a utilização de tal modalidade societária está em constante ascensão e evolução e tem previsão legal expressa no art. 981, parágrafo único, do $\mathrm{CC} / 2002^{16}$.

A SPE não possui personalidade jurídica por si só, devendo por tal motivo, necessariamente adotar uma das modalidades societárias estabelecidas em lei, de maneira que o modelo adotado é que servirá para conferir sua personalidade jurídica própria, que passa a existir a partir de sua constituição.

Dessa maneira, fica ela submissa ao modelo societário que adotar quando de sua constituição, sendo por este regida. Portanto, não é demais salientar que a SPE não poderá valer-se dos tipos societários que não possuem personalidade jurídica, eis que sua personalidade jurídica fica condicionada à modalidade adotada.

A SPE é constituída por meio de contrato ou estatuto social, cujas cláusulas se darão nos moldes do tipo societário que será por ela adotado. Por adotar sempre o formato de sociedade empresária, seu contrato ou estatuto social deverá ser necessariamente arquivado perante a Junta Comercial competente.

Em sendo uma sociedade empresária, para a sua constituição é necessário que sejam observados os requisitos do art. 997 do $\mathrm{CC} / 2002^{17}$, além daqueles fixados pela modalidade societária para ela selecionada.

Desse modo, em revestindo a forma de sociedade anônima, os requisitos concernentes a esta última é que devem ser observados por ocasião de sua constituição e assim, sucessivamente, conforme a modalidade societária por ela adotada.

\footnotetext{
${ }^{16}$ BRASIL. Código Civil (2002). Lei nº ${ }^{\circ}$ 10.406, de 10 de janeiro de 2002. Diário Oficial da União, 11 jan. 2001.

Art. 981. Celebram contrato de sociedade as pessoas que reciprocamente se obrigam a contribuir, com bens ou serviços, para o exercício de atividade econômica e a partilha, entre si, dos resultados.

Parágrafo Único. A atividade pode restringir-se à realização de um ou mais negócios determinados.

${ }^{17}$ BRASIL. Código Civil (2002). Lei no $\mathrm{n}^{\circ}$ 10.406, de 10 de janeiro de 2002. Diário Oficial da União, 11 jan. 2001.

Art. 997. A sociedade constitui-se mediante contrato escrito, particular ou público, que, além de cláusulas estipuladas pelas partes, mencionará:

I - nome, nacionalidade, estado civil, profissão e residência dos sócios, se pessoas naturais, e a firma ou a denominação, nacionalidade e sede dos sócios, se jurídicas;

II - denominação, objeto, sede e prazo da sociedade;

III - capital da sociedade, expresso em moeda corrente, podendo compreender qualquer espécie de bens, suscetíveis de avaliação pecuniária;

IV - a quota de cada sócio no capital social, e o modo de realizá-la;

$\mathrm{V}$ - as prestações a que se obriga o sócio, cuja contribuição consista em serviços;

VI - as pessoas naturais incumbidas da administração da sociedade, e seus poderes e atribuições;

VII - a participação de cada sócio nos lucros e nas perdas;

VIII - se os sócios respondem, ou não, subsidiariamente, pelas obrigações sociais.Parágrafo único. É ineficaz em relação a terceiros qualquer pacto separado, contrário ao disposto no instrumento do contrato.
} 
Em geral a SPE reveste-se na forma de sociedade anônima e é utilizada para consecução de um projeto específico. É, portanto, um meio utilizado por sua controladora a fim de que alcance o objetivo social almejado.

As SPE's podem ser formadas apenas por pessoas jurídicas, pela união dessas primeiras com pessoas físicas e, embora não ocorra com frequência, exclusivamente por pessoas físicas, tal como ocorre nas demais modalidades empresárias.

No que tange à relação entre os sócios que dela participam, tanto a esfera interna, quanto a externa serão regidas por seu contrato social. Sobre a questão, não é demais salientar que o tipo societário eleito para reger a SPE regulará também os direitos e as responsabilidades dos sócios.

Destarte, a SPE objetiva o fomento de negócios específicos, bem como promover o crescente desenvolvimento econômico no país, sendo vantajosa na medida em que, sendo limitada a um único projeto, tem seus próprios interesses que não se confundem com os interesses de seus controladores, além de possuir personalidade jurídica e autonomia próprias.

Por tais razões, é modalidade que traz benefícios aos seus sócios eis que não se mistura com demais atividades por eles desempenhadas, o que é benéfico para a angariação de investimentos, além de permitir aos seus investidores acesso menos complexo aos recursos do projeto.

Destarte, quando de sua constituição, a SPE pode tomar a forma de qualquer sociedade empresária constante do ordenamento jurídico pátrio, permitindo aos seus sócios eleger a modalidade societária mais adequada às suas necessidades e, ainda, que a responsabilidade dos seus sócios seja limitada conforme o tipo societário adotado.

Dessa maneira, caso a SPE seja constituída sob a forma de sociedade limitada, a responsabilidade dos sócios ficará adstrita ao valor de suas quotas sociais, embora todos sejam solidariamente responsáveis pela integralização do capital social, conforme disposto no CC/2002. No entanto, caso se revista sob a forma de sociedade anônima, a responsabilidade dos acionistas é restringida ao valor de emissão das ações subscritas ou adquiridas, nos termos da Lei ${ }^{\circ}$ 6.404/1976.

Uma vez que a SPE trata-se de sociedade empresária nos termos estabelecidos pelo $\mathrm{CC} / 2002$, estabelecida com a finalidade de alcançar um objetivo específico, podendo ser encerrada ou renovada ao final do projeto, deve necessariamente adotar ma das modalidades societárias existente no ordenamento jurídico pátrio, servindo este 
último para regular as questões concernentes à sua dissolução, liquidação e extinção.A SPE tem seu objeto adstrito ao alcance do objeto social da sociedade e, por tal razão, é também determinado o seu prazo de duração, ainda que não haja determinação de prazo de legal para a modalidade societária que abraçar, já que a existência da SPE está diretamente ligada ao cumprimento de sua finalidade, à execução de um projeto específico. Por tal razão, constarão nos cadastros das Juntas Comerciais, por ocasião do arquivamento das sociedades de propósito especifico a data em que se iniciam além da fixação de termo para o seu encerramento, conforme projeto a ser desenvolvido.

A SPE é modalidade societária que pode ser utilizada nos mais diversos projetos, com o benefício de ser criada para o desempenho de um objeto determinado.

Como já abordado, nas operações de securitização de recebíveis, o lastro para emitir os títulos que os investidores venham a adquirir consistem em obrigações futuras, que serão quitadas em favor da sociedade emissora.

Tal pode se dar por meio da criação de uma SPE, que será responsável pela administração do ativo que o originador lhe transferiu. Assim, o originador é o sujeito que institui determinada e para ela realiza a transferência de ativos, que podem consistir integral ou parcialmente em direitos creditórios futuros. A SPE, por sua vez poderá emitir títulos com lastro nos recebíveis que lhe foram transferidos, com a consequente captação no mercado financeiro, de recursos que deles advenham.

Quando utilizada nas operações de securitização, a SPE pode ter como seu propósito específico exclusivamente a angariação de capitais provenientes da securitização de recebíveis.

Acerca da utilidade da SPE em relação à securitização de recebíveis, veja-se as palavras de Alexandre Assaf Neto ${ }^{18}$ :

(...) a securitização de recebíveis é realizada geralmente por empresas que apresentam uma carteira bastante pulverizada de valores a receber, em que nenhum recebível represente parcela relevante de seu total. A empresa tomadora de recursos negocia sua carteira de recebíveis com uma empresa Sociedade de Fins Especiais (Special Purpose Company) a qual levanta recursos no mercado mediante a emissão de títulos (geralmente debêntures) lastreados nesses valores adquiridos.

Ainda sobre a questão, as considerações de Eduardo Fortuna ${ }^{19}$ :

$\mathrm{Na}$ forma clássica destas operações, cria-se uma SPC cujo objetivo será exclusivamente adquirir os recebíveis da empresa que a constituiu pela emissão de debêntures. Como os recebíveis são normalmente de curto prazo e

\footnotetext{
${ }^{18}$ NETO, Alexandre Assaf. Mercado Financeiro, $5^{\text {a }}$ ed. Editora Atlas, São Paulo, 2003. p. 129.

${ }^{19}$ FORTUNA, Eduardo. Mercado Financeiro: produtos e serviços. $15^{\mathrm{a}}$ edição. Editora Quality. Rio de Janeiro, 2003. p. 259.
} 
as deêntures, de longo prazo, a SPC vai ter caixa muito antes do vencimento das debêntures.

No que tange às vantagens da securitização de recebíveis por meio de uma SPE, as palavras de $\mathrm{Caminha}^{20}$ :

\begin{abstract}
A característica mais marcante e, ao mesmo tempo, uma das maiores vantagens da operação de securitização é a segregação do lastro dos títulos emitidos num veículo distinto do originador dos créditos.

Essa característica apresenta-nos como vantagem tanto para os originadores quanto para os investidores. Para os primeiros, por permitir-lhes uma operação que, em princípio não será registrada em suas demonstrações financeiras e que, por não incorporar os riscos de uma empresa operacional, poderá ter melhor classificação de risco, em comparação com o próprio originador, e, por conseguinte, menor exigência de taxas por parte dos investidores e prazo mais longo para financiamento da dívida. Para os investidores, o menor risco significa maior segurança em investimentos, que, em tese, serão mais rentáveis que aqueles tradicionalmente apresentados no mercado.
\end{abstract}

A SPE está diretamente ligada às operações de securitização de créditos imobiliários, uma vez que, estas se constituem de operação financeira em que determinada sociedade de propósito específico (SPE) emite títulos em favor dos investidores, seja de maneira direta ou indireta, empregando o capital obtido para adquirir os direitos de liquidação, que constituirão a fonte principal de pagamento de tais títulos.

Assim sendo, a SPE objetiva a promoção de projetos específicos, seus interesses não se permutam com os interesses individuais de seus gestores, além de possuir autonomia e personalidade jurídica próprias, o que é extremamente proveitoso para a operações de securitização de créditos imobiliários e estimula o crescimento do cenário econômico atual, em específico, no que tange ao mercado imobiliário.

\title{
4- CONCLUSÃO
}

A securitização é um modelo de estruturação financeira que viabiliza ao originador do crédito o acesso direto ao mercado de capitais e, atualmente é relevante instrumento. De maneira simplificada, as operações de securitização dizem respeito à cessão de créditos de uma sociedade originadora a uma sociedade criada

\footnotetext{
${ }^{20}$ CAMINHA, Uinie. Securitização. $2^{a}$ edição. São Paulo: Saraiva, 2007. pp. 108-109.
} 
exclusivamente com a finalidade de receber estes e emitir títulos com lastro nos créditos que lhe são aportados.

Já há algum tempo os títulos cambiários são empregados também com o objetivo de atrair investimentos no âmbito dos mercados capitais e financeiro, o que se dá por intermédio de sua comercialização.

Assim, no que tange ao setor imobiliário, a de créditos imobiliários desempenha papel de grande importância, possibilitando inclusive a transformação de ativos que não possuem liquidez em títulos mobiliários.

Ao realizar a securitização de créditos imobiliários, tem a instituição financeira a faculdade de colocá-los para circulação nos mercados de capitais e financeiro, não necessitando, portanto esperar até que seja realizado o pagamento do direito creditório que possui, podendo transmutá-los em valores mobiliários, que ao serem utilizados neste contexto denominam-se CRIs.

Com a inserção dos CRIs nos mercados de capitais e financeiro, nasce também a possibilidade de negociação de tais títulos por seus adquirentes ou mesmo a possibilidade de execução do imóvel que ensejou a sua emissão.

A SPE pode ser utilizada nas operações de securitização, isso é dizer que, é usada em operações em que determinados ativos são separados do patrimônio do originador, para em seguida serem emitidos títulos que representem o seu conjunto de créditos.

Quando uma SPE é utilizada na securitização de recebíveis, esta será responsável pela gestão do ativo que lhe repassa o originador, que é também o sujeito ao qual caberá constituir a SPE. Uma vez criada, a SPE terá a possibilidade de emitir títulos que tenham como lastro os recebíveis que lhe foram repassados, com a consequente captação de capital no mercado financeiro a partir da emissão destes títulos.

Os riscos intrínsecos à captação de capitais em operações de securitização de recebíveis, com a utilização de uma SPE, são mensurados tanto pelo tomador de recursos quanto pelo credor. O tomador é o sujeito que contrai obrigações, com a manutenção dos bens dos sócios no caso de obrigações que sejam inadimplidas em relação àqueles que sejam exclusivamente credores da SPE, separadas daquelas assumidas pelos sócios da SPE.

No que diz respeito às operações de securitização de créditos imobiliários, a SPE está diretamente ligada a tais operações já que, essas tratam-se de operação 
financeira em que determinada sociedade de propósito específico (SPE) emite títulos em favor dos investidores, direta ou indiretamente, com a aplicação do crédito alcançado para a aquisição dos direitos de liquidação, que constituirão a fonte principal de pagamento de tais títulos.

\section{REFERÊNCIAS}

ASSOCIAÇÃO BRASILEIRA DE NORMAS E TÉCNICAS. NBR 10520/2002: informação e documentação: citações em documentos: apresentação. Rio de Janeiro, 2002.

ASSOCIAÇÃO BRASILEIRA DE NORMAS E TÉCNICAS. NBR 6023/2002: informação e documentação: referências: elaboração. Rio de Janeiro, 2002.

ASSOCIAÇÃO BRASILEIRA DE NORMAS E TÉCNICAS. NBR 6022/2003: informação e documentação: referências: elaboração. Rio de Janeiro, 2003.

ASSOCIAÇÃO BRASILEIRA DE NORMAS E TÉCNICAS. NBR 6024/2003: informação e documentação: referências: elaboração. Rio de Janeiro, 2003.

BALBINO FILHO, Nicolau. Registro de Imóveis: doutrina, prática e jurisprudência. 14. ed. São Paulo: Editora Saraiva, 2009.

BATALHA, Wilson de Souza Campos. Comentários à Lei de Registros Públicos: Lei no 6.015, de 31 de dezembro de 1973. 4. ed. Rio de Janeiro: Editora Forense, 1997.

BRASIL. Constituição da República Federativa do Brasil, de 5 de outubro de 1988 . Brasília: Senado Federal, 1988.

BRASIL. Lei no . 4.380, de 21 de agosto de 1964. Diário Oficial da União, 11 set. 1964.

BRASIL. Lei $n^{\circ} 6.015$, de 31 de dezembro de 1973. Dispõe sobre os registros públicos e dá outras providências. Diário Oficial da União. Brasília, 3 dez. 1973.

BRASIL. Lei ${ }^{\circ}$ 6.766/1979, de 19 de dezembro de 1979. Dispõe sobre o Parcelamento do Solo Urbano e dá outras providências. Diário Oficial da União. Brasília, 20 dez. 1979.

BRASIL. Lei $\mathrm{n}^{\circ}$ 9.514, de 20 de novembro de 1997. Dispõe sobre o Sistema de Financiamento Imobiliário, institui a alienação fiduciária de coisa imóvel e dá outras providências. Diário Oficial da União. Brasília, 24 nov. 1997.

BRASIL. Lei $n^{\circ}$ 10.406, de 10 de janeiro de 2002. Institui o Código Civil. Diário Oficial da União. Brasília, 11 jan. 2002. 
BRASIL. Lei $\mathrm{n}^{\mathrm{o}} 10.931$, de 02 de agosto de 2004. Dispõe sobre o patrimônio de afetação de incorporações imobiliárias, Letra de Crédito Imobiliário, Cédula de Crédito Imobiliário, Cédula de Crédito Bancário, altera o Decreto-Lei $n^{\circ} 911$, de $1^{\circ}$ de outubro de 1969, as Leis $\mathrm{n}^{\circ} 4.591$, de 16 de dezembro de 1964 , $\mathrm{n}^{\circ} 4.728$, de 14 de julho de 1965 , e $\mathrm{n}^{\circ} 10.406$, de 10 de janeiro de 2002, e dá outras providências. Diário Oficial da União. Brasília, 3 ago. 2004.

BRASIL. Lei $\mathrm{n}^{\circ} 21.424$, de 16 de junho de 2011. Altera a Lei no 11.977, de 7 de julho de 2009, que dispõe sobre o Programa Minha Casa, Minha Vida - PMCMV e a regularização fundiária de assentamentos localizados em áreas urbanas, as Leis nos 10.188, de 12 de fevereiro de 2001, 6.015, de 31 de dezembro de 1973, 6.766, de 19 de dezembro de 1979, 4.591, de 16 de dezembro de 1964, 8.212, de 24 de julho de 1991, e 10.406, de 10 de janeiro de 2002 - Código Civil; revoga dispositivos da Medida Provisória no 2.197-43, de 24 de agosto de 2001; e dá outras providências. Diário Oficial da União. Brasília, 17.6.2011 e republicado em 20.6.2011.

CAMINHA, Uinie. Securitização. $2^{\text {a }}$ edição. São Paulo: Saraiva, 2007.

CAMINHA, Uinie. Aspectos conceituais da securitização. Estudos Avançados de Direito Empresarial- Contratos, direito Societário e Bancário, Rio de Janeiro: Editora Campus, 2012.

CARVALHO, Afrânio de. Registro de Imóveis: comentários ao Sistema de Registro em face da Lei $n^{\circ} 6.015$, de 1973, com alterações da Lei $n^{\circ} 6.216$, de 1975, Lei $n^{\circ} 8009$, de 1990, e Lei $n^{\circ}$ 8.935, de 1994, de 18.11.1994. 4. ed. Rio de Janeiro: Editora Forense, 1998.

CENEVIVA, Walter. Lei de Registros Públicos comentada. 18. ed. São Paulo: Editora Saraiva, 2008.

CHALHUB, Melhim Namem. Negócio Fiduciário. Rio de Janeiro: Editora Renovar, 2000.

CHAVES, Natália Cristina. Direito empresarial: securitização de crédito. 1. ed. Belo Horizonte: Del Rey, 2006.

COELHO, Lívia Alves Viesnevski Fróes. Securitização. São Paulo: Potifícia Universidade Católica de São Paulo, 2007.

CRUZ, Antônio Augusto Bello Ribeiro da Cruz. A sociedade de propósito específico: uma visão sob a ótica da personalidade jurídica e da limitação de responsabilidade. Nova Lima: Faculdade de Direito Milton Campos/ FDMC, 2012.

DINIZ, Maria Helena. Código Civil Anotado. 15. ed. São Paulo: Saraiva, 2010.

DINIZ, Maria Helena. Sistema de Registro de Imóveis. 8. ed. São Paulo: Editora Saraiva, 2009. 
FERNANDES, Jean Carlos. Teoria contemporânea dos títulos de crédito: imperativos principiológicos sob a ótica das teorias pós-positivistas. 1. ed. Belo Horizonte: Arraes Editores, 2012.

FORTUNA, Eduardo. Mercado Financeiro: produtos e serviços. $15^{\text {a }}$ edição. Editora Quality. Rio de Janeiro, 2003. p. 259.

KONNO, Alyne Yumi. Registro de Imóveis: teoria e prática. 2. ed. São Paulo: Editora Memória Jurídica, 2010.

LOUREIRO, Luiz Guilherme. Registros Públicos: teoria e prática. 1. ed. São Paulo: Editora Método, 2010.

MORAES, Alexandre de. Direito Constitucional. 13. ed. São Paulo: Editora Atlas, 2003.

NERY JUNIOR, Nelson. Código civil comentado / Nelson Nery Junior, Rosa Maria de Andrade Nery, 9.ed. São Paulo: Editora Revista dos Tribunais, 2012.

NETO, Alexandre Assaf. Mercado Financeiro, 5a ed. Editora Atlas, São Paulo, 2003.

PEDROTTI, Irineu Antonio. Condomínio e incorporações: anotações, legislações, modelos, jurisprudência. / Irineu Antonio Pedrotti, William Antonio Pedrotti; colaboração de Cristiane Minelli de Sá. 1. ed. Sâo Paulo: Editora Juarez de Oliveira, 2001.

OLIVEIRA, Débora Catizane de. Certificados de Recebíveis Imobiliários e seus Reflexos no Desenvolvimento do Mercado Imobiliário. Nova Lima: Faculdade de Direito Milton Campos/ FDMC, 2014.

OLIVEIRA, Nelson Corrêa de. Aplicações do Direito na prática notarial e registral. 3. ed. Porto Alegre: Editora Síntese, 2007.

PEREIRA, Caio Mário da Silva. Condomínio e incorporações. 10. ed. atual. Rio de Janeiro: Forense, 2001.

REQUIÃO, Rubens. Curso de Direito Comercial. Vol. 1. 25. ed. atual. São Paulo: Saraiva, 2003.

TOLEDO, Margherita Coelho. A sociedade de propósito específico no âmbito do direito empresarial brasileiro. Nova Lima: Faculdade de Direito Milton Campos/ FDMC, 2009.

TUTIKIAN, Cláudia Fonseca. Da Incorporação Imobiliária: Implementação do Direito Fundamental à Moradia. 1. ed. São Paulo: Quartier Latin, 2008.

VENOSA, Silvio de Salvo. Código Civil Interpretado. São Paulo: Atlas, 2010. 